\title{
Publication patterns in the social sciences and humanities: evidence from eight European countries
}

\author{
Emanuel Kulczycki ${ }^{1}$ (D) Tim C. E. Engels ${ }^{2} \cdot$ Janne Pölönen $^{3}$ • \\ Kasper Bruun $^{4} \cdot$ Marta Dušková $^{5} \cdot$ Raf Guns $^{2} \cdot$ Robert Nowotniak $^{6}$ • \\ Michal Petr ${ }^{7} \cdot$ Gunnar Sivertsen $^{8} \cdot$ Andreja Istenič Starčič $^{9,10}$ • \\ Alesia Zuccala ${ }^{11}$
}

Received: 14 January 2018/Published online: 26 March 2018

(C) The Author(s) 2018

\begin{abstract}
This study investigates patterns in the language and type of social sciences and humanities (SSH) publications in non-English speaking European countries to demonstrate that such patterns are related not only to discipline but also to each country's cultural and historic heritage. We investigate publication patterns that occur across SSH publications of the whole of the SSH and of economics and business, law, and philosophy and theology publications in the Czech Republic, Denmark, Finland, Flanders (Belgium), Norway, Poland, Slovakia, and Slovenia. We use data from 74,022 peer-reviewed publications from 2014
\end{abstract}

Emanuel Kulczycki

emek@amu.edu.pl

Tim C. E. Engels

tim.engels@uantwerpen.be

Janne Pölönen

janne.polonen@tsv.fi

Kasper Bruun

kasb@ufm.dk

Marta Dušková

marta.duskova@cvtisr.sk

Raf Guns

raf.guns@uantwerpen.be

Robert Nowotniak

rnowotniak@kis.p.lodz.pl

Michal Petr

petr@rect.muni.cz

Gunnar Sivertsen

gunnar.sivertsen@nifu.no

Andreja Istenič Starčič

andreja.starcic@gmail.com

Alesia Zuccala

a.zuccala@hum.ku.dk 
registered in at least one of the eight countries' national databases and for 272,376 peerreviewed publications from the period of 2011-2014 registered in at least one of the seven countries' national databases (for all countries except Slovakia). Our findings show that publication patterns differ both between fields (e.g. patterns in law differ from those in economics and business in the same way in Flanders and Finland) and within fields (e.g. patterns in law in the Czech Republic differ from patterns in law in Finland). We observe that the publication patterns are stable and quite similar in West European and Nordic countries, whereas in Central and Eastern European countries the publication patterns demonstrate considerable changes. Nevertheless, in all countries, the share of articles and the share of publications in English is on the rise. We conclude with recommendations for science policy and highlight that internationalization policies in non-English speaking countries should consider various starting points and cultural heritages in different countries.

Keywords Publication patterns - Social sciences $\cdot$ Humanities $\cdot$ Language $\cdot$ Publication type $\cdot$ Internationalization

\section{Mathematics Subject Classification 00-02}

\section{JEL Classification I23}

\section{Introduction}

This study aims to advance the knowledge regarding social sciences and humanities (SSH) publication patterns in Europe. National studies on SSH research outputs in Finland (Puuska 2014), Flanders (Engels et al. 2012; Verleysen et al. 2014), and Norway (Sivertsen 2016a) have reported

1 Scholarly Communication Research Group, Faculty of Social Sciences, Adam Mickiewicz University in Poznań, Szamarzewskiego 69, 60-568 Poznań, Poland

2 Centre for R\&D Monitoring, Faculty of Social Sciences, University of Antwerp, Middelheimlaan 1, 2020 Antwerp, Belgium

3 Federation of Finnish Learned Societies, Snellmaninkatu 13, 00170 Helsinki, Finland

4 Division of Analysis, Statistics and Coordinated Admission, Agency for Science and Higher Education, Danish Ministry of Higher Education and Science, Bredgade 40, 1260 Copenhagen, Denmark

5 Slovak Centre of Scientific and Technical Information, Lamačská cesta 8/A, 81104 Bratislava, Slovak Republic

6 Faculty of Electrical, Electronic Computer, and Control Engineering, Institute of Applied Computer Science, Lodz University of Technology, Lodz, Poland

7 Research Office, Masaryk University, Zerotinovo namesti 9, 60177 Brno, Czech Republic

8 Nordic Institute for Studies in Innovation, Research and Education, P.O. Box 2815, 0608 Toyen, Oslo, Norway

9 Faculty of Civil and Geodetic Engineering, University of Ljubljana, Jamova 2, 1000 Ljubljana, Slovenia

10 Faculty of Education, University of Primorska, Cankarjeva 5, 6000 Koper, Slovenia

11 Department of Information Studies, University of Copenhagen, Njalsgade 76, 2300 Copenhagen, Denmark 
stable patterns in terms of publication type; however, in terms of publication language, academic work is gradually leaning toward greater use of English. Van Leeuwen (2006) reported similar patterns of referencing non-Institute for Scientific Information-covered sources among social scientists from six different countries. Furthermore, Sivertsen (2016a) suggests that, although publication patterns differ between SSH disciplines, these patterns are rather similar within SSH disciplines across different countries. However, very few cross-country comparative studies of SSH publication patterns have been conducted. Moreover, these studies have focused on West European and Nordic countries (e.g. Nordforsk 2018; Ossenblok et al. 2012; Pölönen et al. 2017a). In this study, we add Central and Eastern European countries, which have undergone various academic transformations over the past three decades, following the breakdown of Communist regimes (Kozak et al. 2014; Kwiek 2014).

All the analysed countries are non-English speaking countries. However, in terms of the scholars working there, internationalization in these countries varies in many ways. For instance, in Finland, the share of foreign academic staff in Finnish universities has increased in SSH fields from 8\% of the full-time equivalent in 2010 to $12 \%$ in 2016 (Vipunen 2017). In the Czech Republic in 2011, less than $10 \%$ of researchers overall were foreign, and half of those were Slovaks (Arnold 2011), whereas the share of foreign academic staff in Polish universities was 2.5\% in 2016 (PAP Nauka w Polsce 2017).

Our study contributes to the literature by demonstrating that in non-English speaking countries, patterns in the language and type of SSH publications are related not only to the norms, culture, and expectations of each SSH discipline but also to each country's specific cultural and historic heritage. The starting point for this study are the results of a previous study we conducted, which were presented at the ISSI 2017 conference in Wuhan, China (Kulczycki et al. 2017a). In this previous study, we investigated all peer-reviewed SSH publications from the 2009-2014 period in Flanders (Belgium) and Poland. In the present study, SSH publication data from eight European countries are included.

We have analysed all scholarly SSH publications for the 2011-2014 period written by academics affiliated with higher education institutions or research institutes from eight European countries: the Czech Republic, Denmark, Finland, Flanders (Belgium), Norway, Poland, Slovakia, and Slovenia. Though the presence of SSH publications in databases like Scopus and the Web of Science Core Collection (WoS) has grown-and though, as a result, various research evaluation systems have come to use this presence as a criterion of productivity - these citation databases have limited coverage of scholarly SSH publications from nonEnglish speaking countries (Sivertsen 2014). Therefore, to develop a broader picture of publication patterns in Europe, we examine the peer-reviewed publications registered in national publication databases, which offer an almost complete representation of scholarly SSH publications within their respective countries. We begin by characterizing these databases and defining various publication types and inclusion criteria. Next, we briefly explain how the databases classify publications into fields and disciplines. Then we describe the data and methods, as well as our findings regarding SSH publication patterns in terms of language and type. We conclude by discussing and interpreting the results in a broader context.

\section{Data sources}

To achieve the study's aim, we use data from eight national databases that comprehensively cover the scholarly, peer-reviewed SSH publications of each of the eight countries. In this way, we investigate all peer-reviewed SSH publications, including journal articles, 
monographs, edited volumes, and chapters in books/conference proceedings, from all eight countries. For each of the databases, whole counting of publications at the national level is applied, meaning that (1) for each of the countries each of the publications is counted once, and that (2) papers co-authored by authors with affiliations in two or more of these eight countries are counted for each of those countries. By using national databases, our study is not limited to publications covered by Scopus or the WoS. In the following, we present the data sources for bibliographic information from each country. We use these databases to cover the entire SSH domain in which data are-or can be-classified in three dimensions:

1. Publication type journal article, monograph, edited volume, or chapter in book/conference proceedings.

2. Publication language English, local language, or other languages.

3. Discipline economics and business, law, and philosophy and theology.

More information about each of the databases and details on the inclusion criteria are available in the ENRESSH Report on European databases for SSH output (Sīle et al. 2017). As will be apparent from the ensuing brief description of each of the databases, the coverage of these databases in terms of included institutions differs. For example, in some cases the publications by authors with a university affiliation only are reported, whereas in other cases the entire higher education and research performing sector is included. The latter design typically adds a few percentages of peer-reviewed publications to a country's total volume. These differences in terms of comprehensiveness of database coverage are discussed in detail by Sīle et al. (n.d.). Here, we maintain that those differences in comprehensiveness of coverage influence the numbers and percentage reported in this paper to a limited extent. In other words, exact numbers and percentages might be subject to change if the comprehensiveness of the databases or the processes underlying them were different; the general trends reported in this paper, however, would remain.

\section{Data sources for peer-reviewed SSH publications}

Below, we describe the design and content of the eight national databases. Moreover, we present the InCites Dataset, which is used to compare the coverage degree between the WoS and the national databases.

\section{Czech Republic: The National Registry of RD \& I Outputs (RIV)}

The data in the RIV is collected through a process that involves the institutions and the funders of research activities (Arnold 2011). Records in the RIV are most often locally created in the current research information systems of higher education institutions. The authors of the publications working in the Czech higher education institutions are responsible for the data quality. However, the final records are verified at the national level. The publication records are collected annually from research organizations via funding bodies to the RIV. The collected data was verified in a specific timeframe (including subject classifications) both algorithmically (i.e. the validity of the whole publication record) and manually by verification panels (i.e. for monographs, chapters, and articles published in Czech journals not indexed in Scopus or the WoS). 


\section{Denmark: The Danish Bibliometric Research Indicator (BFI)}

The BFI is an instrument for the performance-based research funding model for the distribution of block grants for research to Danish universities (Ministry of Higher Education and Science and Danish Agency for Science and Higher Education 2017). With the Danish database, all publication records affiliated with eight Danish universities were collected from current individual research information systems and then de-duplicated. Depending on the university, it may be either the authors of the publication or the department itself that takes responsibility for the quality of the data input. Moreover, the inclusion criteria for the BFI are always decided by the Academic as well as a National Steering Committee. Bibliographic information about publication types and publication languages within the disciplines were not collected in Denmark before 2008.

\section{Flanders (Belgium): The Flemish Academic Bibliographic Database for the Social Sciences and Humanities (VABB-SHW)}

Earlier studies have described the methodology and the inclusion criteria of the VABBSHW for collecting bibliographic data (Verleysen et al. 2014). Five Flemish universities annually provide bibliographic information for publications from the previous 2 years. The interuniversity Centre for Research and Development Monitoring (ECOOM) serves as the database coordinator and technical operator. Moreover, the Flemish government has established an authoritative panel comprised of 18 professors affiliated with Flemish universities, and this panel evaluates whether journals and book publishers fulfil the VABB-SHW's inclusion criteria.

\section{Finland: The VIRTA Publication Information Service}

In Finland, the publication records on all publications, including SSH, are collected at the national level in the VIRTA database (Ministry of Education and Culture 2015). These data are used in the performance-based research funding system for allocating parts of the block grants to universities. The inclusion criteria are decided by the Ministry of Education and Culture. The VIRTA database integrates publication data from fourteen separate institutional CRIS systems. Peer-review status and field of publications are determined at the record level at the time of registering publications to local CRIS systems. The publication data are validated by the higher education institutions. Some universities update publication records daily, and some universities report all publications once a year.

\section{Norway: Norwegian Science Index (NSI)}

The Norwegian Science Index (NSI) is a part of the CRIStin database, which collects publication records from all fields at higher education institutions, hospitals and independent research institutes. The Norwegian model (Sivertsen 2016b) with a publication indicator for institutional funding was one of the motivations for establishing the CRIStin. The CRIStin is updated daily. However, once a year, official quality assured data are published. In the CRIStin, data on publications are with a few exceptions only from organizations funded by the Ministry of Education and Research (higher education), the Ministry of Health (hospitals), and the Research Council (research institutes). The NSI records three scholarly publication types: Articles in journals and series, articles in books, 
and books. For the funding model, publication channels are divided into two levels according to their prestige.

\section{Poland: The Polish Scholarly Bibliography (PBN)}

The database's records are used for Poland's performance-based research funding system. The inclusion criteria and publication types have been described in previous studies (Kulczycki 2017). In Poland, all scientific units (including faculties, basic and applied research institutions, and the Polish Academy of Sciences) must submit to the PBN all bibliographic information for their affiliated scholarly publications. The database is updated daily, and the data are verified by PBN editors and higher education administrators. Each scientific unit must submit its data at least once every 6 months. However, missing data can be added until the next cycle of scientific unit evaluation, which is conducted every 4 years.

\section{Slovakia: The Central Registry of Publication Activity (CREPČ)}

Run since 2007, the CREPČ is a bibliographical database collecting metadata of publications from all Slovakian universities (public, state, private). The database mainly serves to allocate state-budget funding to public universities. The Ministry of Education, Science, Research and Sport of the Slovak Republic regulates what data-reported by academic libraries_on the peer-reviewed publications are provided (Hrčková and Dušková 2011). The bibliographic records are registered by librarians in academic libraries. The Slovak Centre of Scientific and Technical Information serves as a verification workplace for bibliographic records as well as for publications. Data from the Slovak Academy of Sciences are not collected because the academy is not obliged to contribute to the CREPČ: the publications are registered in its own system based on almost the same rules as those of the CREPC system. Publication data are provided for authors with a full-time academic position. In the CREPČ, publications are reported and assigned to a detailed classification of publication types for which there are specific inclusion criteria (Ministry of Education, Science, Research and Sport of the Slovak Republic 2012). In this database, information on disciplines assigned to publications is provided since 2014.

\section{Slovenia: The Cooperative Online Bibliographic System and Services (COBISS)}

The COBISS, which is a national library information system (COBISS Platform 2016), supports the Slovenian Current Research Information System (SICRIS 2009) by linking to Scopus and the WoS. The bibliographic records are registered by librarians. Publication types are assigned to publications in agreement with the guidelines set by the Slovenian Research Agency and are controlled by Central Specialised Information Centres. The data are assigned to (a refined version of) the Organization for Economic Co-operation and Development Fields of Science (OECD FOS) according to the guidelines set by the Slovenian Research Agency. 


\section{Web of Science Core Collection: InCites Dataset}

To compare the coverage degree between the WoS and the national databases, we use data about the number of publications from the InCites Dataset for seven countries and for all Flemish universities and public research institutes (we counted joint publications from these Flemish institutions only once). InCites Dataset contains Science Citation Index Expanded, Social Sciences Citation Index, Arts \& Humanities Citation Index, Conference Proceedings Citation Index-Science, Conference Proceedings Citation Index-Social Sciences \& Humanities, Book Citation Index-Science, and Book Citation Index-Social Sciences \& Humanities. We use all publication types (including editorials, abstracts, etc.) registered in the WoS from 2011 to 2014, which are classified into one of two OECD FOS fields: the social sciences and the humanities.

\section{Publication types and languages}

The above-mentioned databases assign a publication type to each publication. Depending on the database, three, four, or more publication types are distinguished. For the purpose of this study, we identified the common denominator for all the databases and classified all the publications into four types: journal articles, monographs, edited volumes, and chapters in books/conference proceedings. For Slovenia, chapters in conference proceedings were not taken into account. Data on edited volumes are not collected in the Czech Republic, Denmark, and Slovakia; in Norway, data on edited volumes, their contents, authors and editors, are collected in CRIStin, but the editing of such volumes does not count as a specific publication type in the funding model and is therefore not specified in the statistics. Table 1 presents the publication types distinguished for each of the databases used in this study.

The data on the publication language is classified into three categories: English, local language, and other. If there is more than one national language, the language that is used most frequently as the publication language in the country or region is defined as local. Local languages are presented in Table 2.

Table 1 Publication types in each of the databases used in this study

\begin{tabular}{|c|c|c|c|c|}
\hline Database & Article & Monograph & $\begin{array}{l}\text { Edited } \\
\text { volume }\end{array}$ & Chapter \\
\hline Czech Republic-The National Registry of RD \& I Outputs & + & + & - & + \\
\hline Denmark-The Danish Bibliometric Research Indicator & + & + & - & + \\
\hline $\begin{array}{l}\text { Flanders-The Flemish Academic Bibliographic Database for } \\
\text { the Social Sciences and Humanities }\end{array}$ & + & + & + & + \\
\hline Finland-The VIRTA Publication Information Service & + & + & + & + \\
\hline Norway-The Norwegian Science Index & + & + & - & + \\
\hline Poland-The Polish Scholarly Bibliography & + & + & + & + \\
\hline Slovakia-The Central Registry of Publication Activity & + & + & - & + \\
\hline $\begin{array}{l}\text { Slovenia-The Cooperative online bibliographic system and } \\
\text { services }\end{array}$ & + & + & + & + \\
\hline
\end{tabular}


Table 2 Local language in each of the databases used in this study

\begin{tabular}{ll}
\hline Database & $\begin{array}{l}\text { Local } \\
\text { language }\end{array}$ \\
\hline Czech Republic_The National Registry of RD \& I Outputs & Czech \\
Denmark-The Danish Bibliometric Research Indicator (Denmark) & Danish \\
Flanders-The Flemish Academic Bibliographic Database for the Social Sciences and & Dutch \\
Humanities & Finnish \\
Finland-The VIRTA Publication Information Service & Norwegian \\
Norway-The Norwegian Science Index & Polish \\
Poland-The Polish Scholarly Bibliography & Slovakian \\
Slovakia-The Central Registry of Publication Activity & Slovene \\
Slovenia-The Cooperative online bibliographic system and services &
\end{tabular}

\section{Discipline classification systems}

According to Daraio and Glänzel (2016), all subject classifications can be reduced to four main types, namely: (1) cognitive-content-related, (2) administrative-responsibilityrelated, (3) organizational-structure-related, and (4) qualification-based-competencyrelated. Table 3 shows the type of subject classification systems used in each of the databases.

In six databases (RIV in the Czech Republic, BFI in Denmark, VIRTA in Finland, NSI in Norway, CREPČ in Slovakia, and COBISS in Slovenia), publications are assigned to

Table 3 Discipline classification systems used in each of the databases for assigning publications to disciplines

Classification system

Cognitive Administrative Organizational Qualification-
based

\begin{tabular}{|c|c|c|c|c|}
\hline $\begin{array}{l}\text { Czech Republic-The National Registry of } \\
\text { RD \& I Outputs }\end{array}$ & + & - & - & - \\
\hline $\begin{array}{l}\text { Denmark-The Danish Bibliometric } \\
\text { Research Indicator (Denmark) }\end{array}$ & + & - & - & - \\
\hline $\begin{array}{l}\text { Flanders-The Flemish Academic } \\
\text { Bibliographic Database for the Social } \\
\text { Sciences and Humanities }\end{array}$ & - & - & + & - \\
\hline $\begin{array}{l}\text { Finland-The VIRTA Publication } \\
\text { Information Service }\end{array}$ & + & - & - & - \\
\hline Norway_-The Norwegian Science Index & + & - & - & - \\
\hline Poland-The Polish Scholarly Bibliography & - & - & + & - \\
\hline $\begin{array}{l}\text { Slovakia-The Central Registry of } \\
\text { Publication Activity }\end{array}$ & + & - & - & - \\
\hline $\begin{array}{l}\text { Slovenia-The Cooperative online } \\
\text { bibliographic system and services }\end{array}$ & + & - & - & - \\
\hline
\end{tabular}


disciplines according to a cognitive classification, mostly the OECD Fields of Science classification or a refined version thereof. This means that the assignment of publications to disciplines is based on the content of publications or journals in which papers were published. In Flanders and Poland, publications are assigned according to the organizational structure of the higher education institutions to which the authors of the publications are affiliated. In this way, all publications of a researcher working at some law faculty are assigned to the law discipline. In Denmark, bibliographic information about publication types and publication languages within the disciplines was not collected for the period analysed in this study. Therefore, the Danish data are not used in the comparison on the discipline level. Slovakia uses discipline classification, which allows for differentiation of SSH from other fields from 2014 onwards. Thus, only the 2014 data can be used for Slovakia. In the WoS, publications are assigned to disciplines and fields according to a cognitive classification, which is mapped to the OECD FOS classification.

\section{Methods}

For the purposes of this study, we analyse the set of all peer-reviewed SSH publications, as well as the publications for specific SSH disciplines. For our analysis, we use the publication data per country for the 2011-2014 period. For each of the countries, the numbers of publications have been reported. We use four datasets to (A) present the total volume of $\mathrm{SSH}$ publications in eight countries, (B) compare the coverage degree between the WoS and the national databases for SSH publications, $(\mathrm{C})$ describe the language and publication type occurrence frequencies in seven countries and to analyse the variability in the proportion of publication types and the variability in the proportion of publication languages for the 2011-2014 period, and (D) present the differences in the use of publication types and languages for economics and business, law, and philosophy and theology in six countries. The four datasets we used are described below:

(A) Dataset A contains statistics for 74,022 publications from 2014 registered in at least one of the eight national databases. For our analysis of the total volume of SSH publications, we used the number of publications per country as our unit of analysis, along with two nominal variables: (1) publication type (article, monograph, edited volume, chapter) and (2) language (English, local language, other).

(B) Dataset B contains statistics for 71,094 publications (i.e. all contained in dataset A except the edited books, as these are included in four out of eight databases only) from 2014 registered in at least one of the eight national databases and for 21,429 publications from 2014 registered in the WoS for seven countries and the Flemish universities and public research institutes. Additionally, this dataset contains statistics for 259,736 publications (edited volumes are not included) from the 2011-2014 period registered in at least one of the seven national databases (all the analysed countries except Slovakia) and for 72,504 publications from the 2011-2014 period registered in the WoS for the same countries and the Flemish universities and public research institutes. For our analysis of the coverage degree of national databases and the WoS, we used the number of publications per country as our unit of analysis, as well as one rank variable: the publication year (2011-2014).

(C) Dataset $\mathrm{C}$ contains statistics for 272,376 publications (edited volumes are included) from the 2011-2014 period registered in at least one of the seven national databases (all countries except Slovakia). For our analysis of the overall SSH publication 
patterns, we used the number of publications per country as our unit of analysis, along with two nominal sub-variables: (1) publication type (article, monograph, edited book, or chapter) and (2) language (English, local, other), as well as one rank variable: the publication year (2011-2014).

(D) Dataset D contains statistics for publications within three disciplines in six countries (all countries except Denmark and Slovakia), including 39,288 economics and business publications; 26,521 law publications; and 16,394 philosophy and theology publications. For our discipline-level analysis of publication patterns in six countries, we used the number of publications per discipline as our unit of analysis, along with the same set of variables used in dataset $\mathrm{C}$.

\section{Results}

\section{Part A: Total volume of SSH publications}

Table 4 shows the distribution of publication types in eight countries in 2014. A total of 74,022 publications from the SSH domain were registered in eight European countries. On average, $56.5 \%$ of the SSH output is in the form of journal articles, while book publications (monographs, edited volumes, and chapters) amount to $43.5 \%$. In the four countries for which edited volumes are considered, their share ranges from almost 3 to just over 15 percent. The share of journal articles is largest in Slovakia (77.1\%) and Flanders (74.8\%), and it is the smallest in Poland (44.8\%). Though there are country-level differences for all publication types, the highest disproportion is between articles and chapters. In most countries, journal articles are the most common publication type, whereas chapters constitute only 12.8 and $20.8 \%$ of all published works in Slovakia and Flanders, respectively. At the same time, chapters constitute 43.1 and $41.8 \%$ of all published works in Poland and Finland, respectively.

Table 5 presents the most commonly used publication languages in each of the eight countries. The highest share of publications in English is in Flanders (78.7\%) and Finland $(68.3 \%)$, and the lowest share is in Poland (17.2\%).

There are substantial differences across the West European and Nordic countries and the Central and Eastern European countries. In Denmark, Finland, Flanders, and Norway, the share of publications in English is (well) over 60\%, whereas in the Czech Republic, Slovakia, and Poland the share is around $25 \%$ or lower. Slovenia, with $46 \%$ of publications in English, seems to hold a middle ground. A limited share of publications that appeared in languages other than English or the local language is observed in all countries except Slovakia, where publications in another language constitute $19.3 \%$ of all SSH publications (the overwhelming majority of those publications are in Czech, which results from recent events in Czechoslovak history).

\section{Part B: total volume of SSH publications in the WoS and national databases}

Table 6 shows the number of SSH publication indexed in the national databases in eight countries and the number of publications in the WoS for these countries in two main OECD Fields of Science: the social sciences and the humanities. In this comparison, we have not included edited volumes in the total number of publications in national databases. 


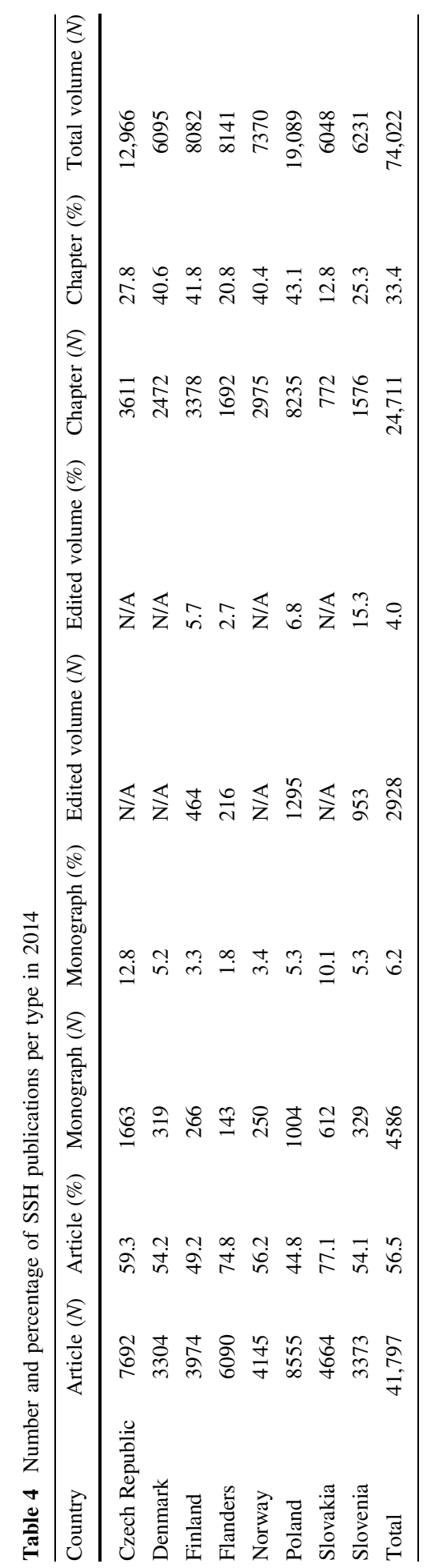


Table 5 Number and percentage of SSH publications per language in 2014

\begin{tabular}{lclllllr}
\hline Country & $\begin{array}{l}\text { English } \\
(N)\end{array}$ & $\begin{array}{l}\text { English } \\
(\%)\end{array}$ & $\begin{array}{l}\text { Local } \\
(N)\end{array}$ & $\begin{array}{l}\text { Local } \\
(\%)\end{array}$ & $\begin{array}{l}\text { Other } \\
(N)\end{array}$ & \multicolumn{1}{l}{$\begin{array}{l}\text { Other } \\
(\%)\end{array}$} & $\begin{array}{l}\text { Total volume } \\
(\mathrm{N})\end{array}$ \\
\hline $\begin{array}{l}\text { Czech } \\
\quad \text { Republic }\end{array}$ & 3418 & 26.4 & 8356 & 64.4 & 1192 & 9.2 & 12,966 \\
Denmark & 3866 & 63.4 & 2041 & 33.5 & 188 & 3.1 & 6095 \\
Finland & 5516 & 68.3 & 1980 & 24.5 & 586 & 7.3 & 8082 \\
Flanders & 6406 & 78.7 & 1372 & 16.9 & 363 & 4.5 & 8141 \\
Norway & 4554 & 61.8 & 2560 & 34.7 & 256 & 3.5 & 7370 \\
Poland & 3285 & 17.2 & 14,742 & 77.2 & 1062 & 5.6 & 19,089 \\
Slovakia & 1562 & 25.8 & 3321 & 54.9 & 1165 & 19.3 & 6048 \\
Slovenia & 2863 & 45.9 & 2717 & 43.6 & 651 & 10.4 & 6231 \\
Total & 31,470 & 42.5 & 37,089 & 50.1 & 5463 & 7.4 & 74,022 \\
\hline
\end{tabular}

Table 6 Number of publications registered in the national databases and the InCites Dataset (WoS) in 2014

\begin{tabular}{lccc}
\hline Country & National databases & WoS & \% of coverage in WoS \\
\hline Czech Republic & 12,966 & 3922 & 30.2 \\
Denmark & 6095 & 3105 & 50.9 \\
Finland & 7618 & 2921 & 38.3 \\
Flanders & 7925 & 3151 & 39.8 \\
Norway & 7370 & 3254 & 44.2 \\
Poland & 17,794 & 2665 & 15.0 \\
Slovakia & 6048 & 1564 & 25.9 \\
Slovenia & 5278 & 847 & 16.0 \\
\hline
\end{tabular}

We assume that, ideally, both each of the national databases and the WoS should cover the total volume of SSH publications from a given country. Per country, we calculate what percentage of the total SSH volume from a given national database is indexed in the WoS. The highest share is for Denmark and Norway, with 50.9 and $44.2 \%$, respectively. The lowest share is for Poland and Slovenia, with 15.0 and $16.0 \%$, respectively.

Figure 1 displays the number of publications according to data sources (national databases versus WoS) from 2011 to 2014. The publications are aggregated from seven countries (all the analysed countries except Slovakia). In 2011, 64,764 publications were registered in national databases, and 15,564 publications were registered in the WoS, whereas in 2014 these numbers slightly increased to 65,046 and 21,429, respectively. Thus, the overall coverage, understood as the percentage of publications from national databases indexed in the WoS, increased from $24.0 \%$ in 2011 to $32.9 \%$ in 2014 in terms of whole counting of publications per country-it may be even lower when considering crossnational co-publications. 




Fig. 1 Number of SSH publications registered in the national databases and the WoS Core Collection from 2011 to 2014 in seven countries: the Czech Republic, Denmark, Finland, Flanders (Belgium), Norway, Poland, and Slovenia

\section{Part C: characteristics of patterns of SSH publications}

Figure 2 displays the number of publications per publication type from 2011 to 2014. The publications are aggregated for the seven countries (all the analysed countries except Slovakia). In 2011, 68,336 publications were registered and in 2014 this number slightly decreased to 67,974. A growth in publication number is observed in all countries except Poland and Slovenia. The number of edited volumes remains stable, whereas there are substantial differences in the number of monographs and chapters, which drop considerably. A growing number of published articles can be observed in all countries.

Figure 3 shows that in the majority of countries, patterns related to publication types were rather stable and quite similar. Edited volumes are not presented in this comparison: we calculated shares for all countries on the basis of articles, monographs, and chapters only. In Poland, we observe considerable changes in the proportions of publication types. The most significant change occurred in 2013: the share of articles increased dramatically. Whereas in 2011 articles constituted $20.71 \%$ of all publications in Poland, by 2014 this proportion increased to $48.08 \%$. The opposite occurred for chapters in Poland, as the share of chapters decreased from $65.04 \%$ in 2011 to $46.28 \%$ in 2014 . The most



Fig. 2 Number of SSH publications per type from 2011 to 2014 in the Czech Republic, Denmark, Flanders (Belgium), Norway, Poland, and Slovenia 

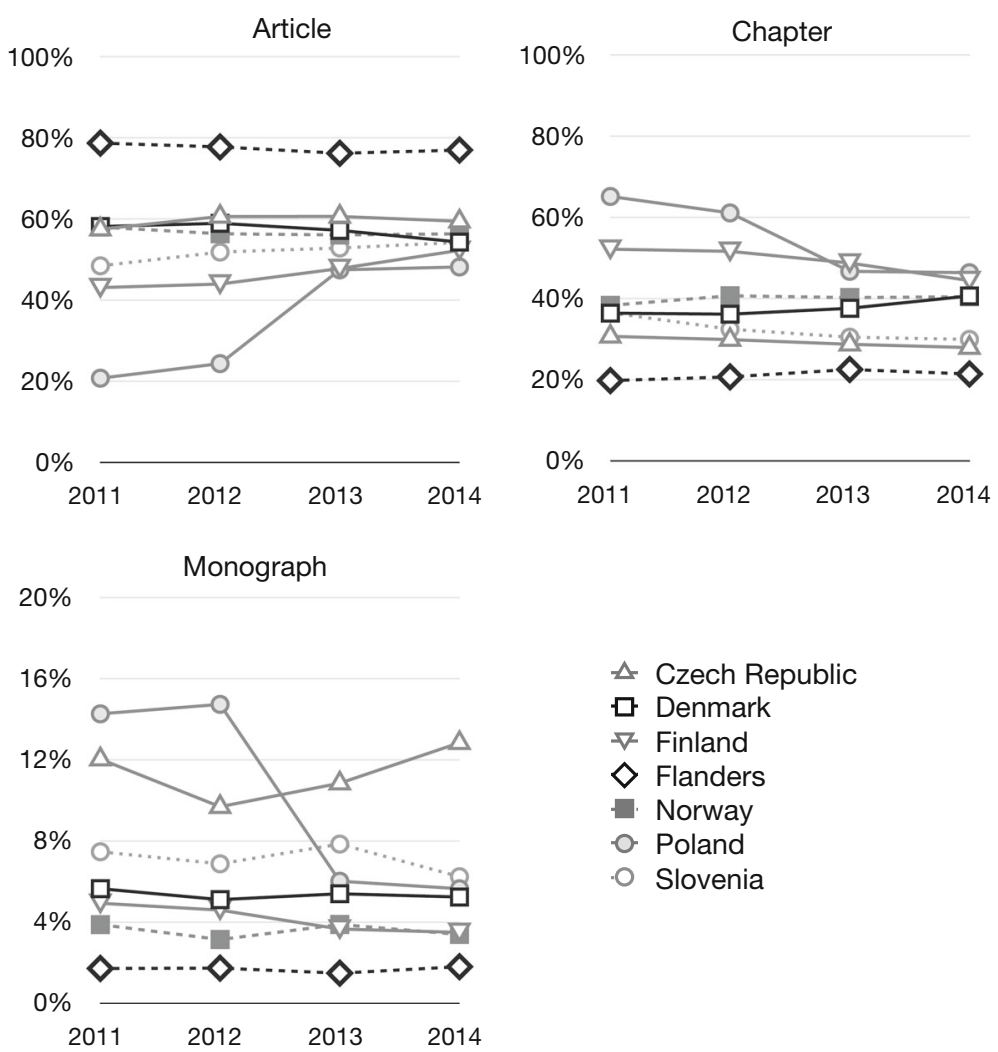

$\triangle$ Czech Republic
$\square$ Denmark
$\nabla-$ Finland
$\diamond$ Flanders
- Norway
$\bullet$ - Poland
$\circ$ Slovenia

Fig. 3 Share of publication types in the 2011-2014 period in seven countries: the Czech Republic, Denmark, Finland, Flanders, Norway, Poland, and Slovenia. The maximum scale value of the vertical axis for 'Article' and 'Chapter' is 100, whereas for 'Monograph' it is 20

significant changes in monograph publishing patterns can be observed in Poland (the decline from $14.25 \%$ in 2011 to 5.64\% in 2014). In 2014, in Denmark, Finland, Flanders, Norway, Poland, and Slovenia monographs do not constitute more than $6 \%$ of the total volume, whereas in the Czech Republic the share of monographs is $12.83 \%$.

Figure 4 shows the distribution of publication languages from 2011 to 2014 (all four publication types included). The proportion of the publications in English is much higher in Denmark, Flanders, Finland, and Norway than in the Czech Republic, Poland, and Slovenia. However, in all countries, there was a growth in the proportion of English publications.

\section{Part D: characteristics of the publication patterns according to three disciplines}

Table 7 shows the distribution of publication types within three disciplines: economics and business, law, and philosophy and theology in six countries. The proportion of articles differed according to disciplines: articles are the dominant publication type within (1) economics and business in the Czech Republic, Flanders, Norway and Slovenia; (2) law in the Czech Republic, Finland, Flanders, Norway, and Slovenia; and (3) philosophy and 

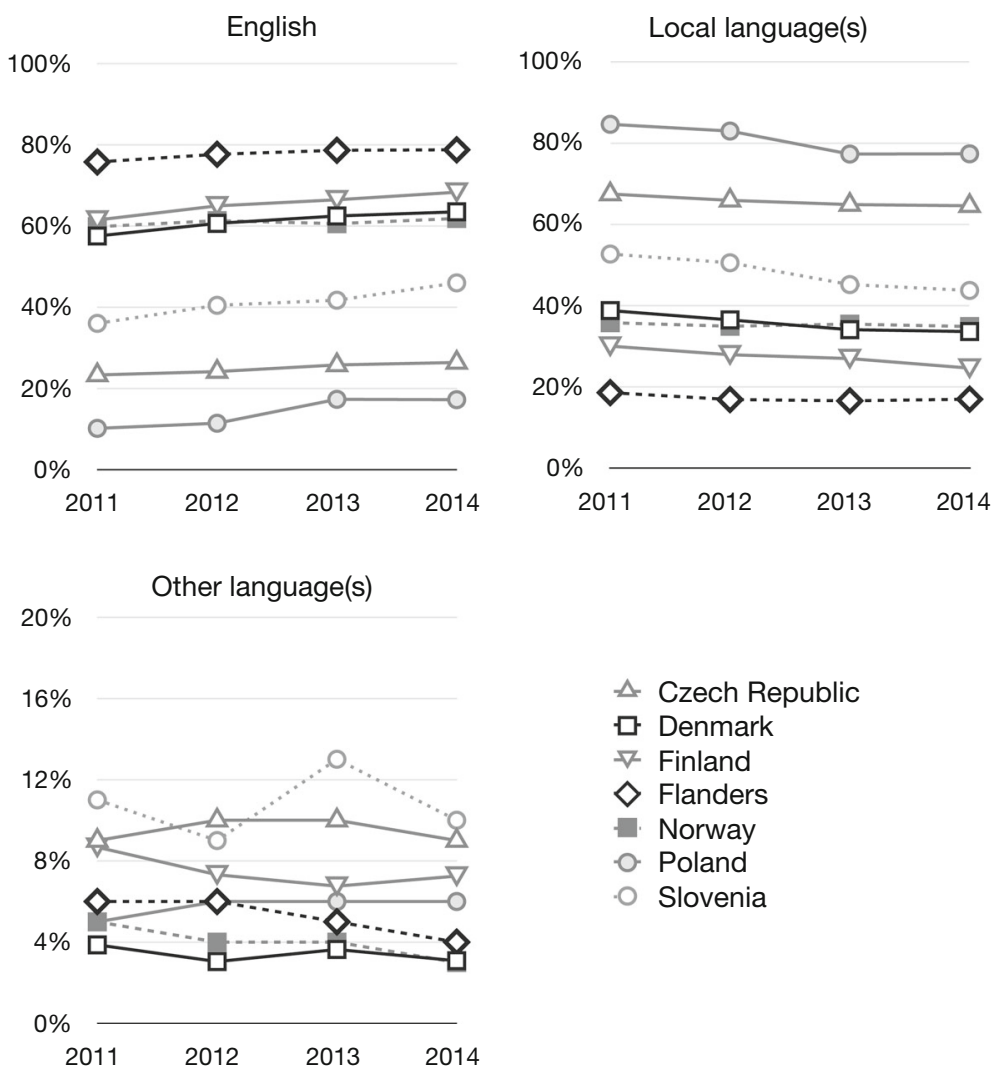

Fig. 4 Publications in English, the local language, and other languages as a percentage of the total (all publication types). The maximum scale value of the vertical axis for 'English and 'Local language(s)' is 100 , whereas for 'Other language(s)' it is 20

theology in the Czech Republic, Flanders, Norway, and Slovenia. In all three disciplines, chapters are the dominant publication type in Poland. Moreover, chapters are the dominant publication type within philosophy and theology in Finland.

Figure 5 presents the proportion of publications in English per countries for economics and business, law, and philosophy and theology.

In all three disciplines, we can observe the same patterns. The highest and stable share of publications in English is in the first group: Finland, Flanders, and Norway. In the second group, the Czech Republic and Slovenia, the share of publications in English is lower than in West European and Nordic countries but higher than in Poland-the only country in the other group-which has the lowest share of publications in English in all disciplines. We can also observe substantial differences among disciplines: in economics and business, the Czech Republic and Slovenia are approaching the trends of West European and Nordic countries. In law, however, the Czech Republic is rather similar to Poland. Nonetheless, in all six countries, a growth of publications in English is observed (except within law in the Czech Republic and Poland). 
Table 7 SSH publications per type and by discipline in six European countries in the 2011-2014 period

\begin{tabular}{lll}
\hline Publication type & $\mathrm{CZ}$ & FIN \\
\hline Economics \& Business
\end{tabular}

Article

$\begin{array}{clllllll}\mathrm{N} & 2732 & 2970 & 3316 & 2845 & 7600 & 1541 & 21,004 \\ \% & 81.31 & 46.38 & 77.77 & 72.78 & 40.23 & 62.67 & 53.46 \\ \begin{array}{c}\text { Monograph } \\ \mathrm{N}\end{array} & & & & & & & \\ \% & 329 & 122 & 51 & 82 & 1529 & 118 & 2231 \\ & 9.79 & 1.91 & 1.20 & 2.10 & 8.09 & 4.80 & 5.68\end{array}$

Edited book

$\begin{array}{llllllll}\mathrm{N} & \mathrm{N} / \mathrm{A} & 142 & 91 & \text { N/A } & 1336 & 369 & 1938 \\ \% & \text { N/A } & 2.22 & 2.13 & \text { N/A } & 7.07 & 15.00 & 4.93\end{array}$

Chapter

$\mathrm{N}$

$\%$

Total

$\mathrm{N}$

Article

$$
\mathrm{N}
$$

$\%$

Monograph

$$
\mathrm{N}
$$

$\%$

Edited book

$$
\mathrm{N}
$$

Chapter

$$
\text { N }
$$

Total

$$
\begin{aligned}
& \mathrm{N} \\
& \%
\end{aligned}
$$

Article

$$
\mathrm{N}
$$

Monograph

$$
\mathrm{N}
$$

$\%$

Edited book

\begin{tabular}{llllllll}
$\mathrm{N}$ & $\mathrm{N} / \mathrm{A}$ & 171 & 126 & N/A & 269 & 258 & 824 \\
$\%$ & $\mathrm{~N} / \mathrm{A}$ & 7.10 & 4.64 & N/A & 7.75 & 12.74 & 5.02 \\
\hline
\end{tabular}

$\begin{array}{lllllll}299 & 3169 & 806 & 982 & 8428 & 431 & 14,115\end{array}$

$\begin{array}{lllllll}8.90 & 49.49 & 18.90 & 25.12 & 44.61 & 17.53 & 35.93\end{array}$

$\begin{array}{lllllll}3360 & 6403 & 4264 & 3909 & 18,893 & 2459 & 39,288 \\ 100 & 100 & 100 & 100 & 100 & 100 & 100\end{array}$

Law

2999

$816 \quad 3042$

821

4241

$1372 \quad 13,291$

64.09

42.37

73.80

51.86

35.83

57.82

50.12

460

$\begin{array}{ll}214 & 94 \\ 11.11 & 228\end{array}$

90

882

157

1897

9.83

11.11

5.69

7.45

6.61

7.15

$\begin{array}{lll}\text { N/A } & 87 & 148\end{array}$

N/A

712

302

1249

N/A

4.52

3.59

N/A

6.01

12.73

4.71

1220

809

\section{8}

672

6003

542

10,084

26.07

42.00

20.33

42.45

50.71

22.84

38.02

4679

$1926 \quad 4122$

1583

11,838

2373

26,521

$\begin{array}{ll}100 & 100 \\ \text { Philosophy \& } & \text { Theology }\end{array}$

$100 \quad 100$

100

100

100

1954

924

1745

$1148 \quad 902$

1043

7716

$54.17 \quad 38.39$

64.25

52.95

25.99

51.51

47.07

460

114
4.74

80

133

529

241

1557

12.75

4.74

2.95

6.13

15.24

11.90

9.50 
Table 7 continued

\begin{tabular}{llllllll}
\hline Publication type & CZ & FIN & FLA & NOR & POL & SI & Total \\
\hline $\begin{array}{lllllll}\text { Chapter } \\
\text { N }\end{array}$ & 1193 & 1198 & 765 & 887 & 1771 & 483 & 6297 \\
$\%$ & 33.07 & 49.77 & 28.17 & 40.91 & 51.02 & 23.85 & 38.41 \\
Total & & & & & & & \\
$\mathrm{N}$ & 3607 & 2407 & 2716 & 2168 & 3471 & 2025 & 16,376 \\
$\%$ & 100 & 100 & 100 & 100 & 100 & 100 & 100 \\
\hline
\end{tabular}

CZ Czech Republic, FIN Finland, FLA Flanders, NOR Norway, POL Poland, SI Slovenia

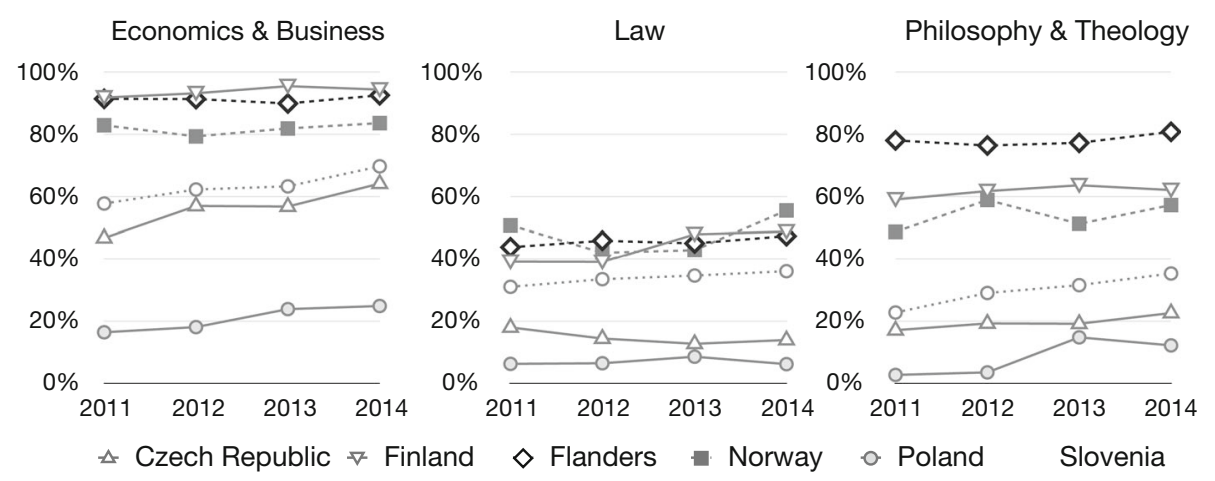

Fig. 5 Publications in English as a percentage of the total (all publication types)

\section{Discussion}

Our findings show that publication patterns differ both across fields (e.g. law differs from economics and business in the same way in Flanders and Finland) and across countries (e.g. publication patterns for law in the Czech Republic differ from those for law in Finland). The advantage of using national publication databases as our data source is that we can analyse the total peer-reviewed SSH publication volume for eight countries and hence go beyond the coverage of databases like Scopus or the WoS. This is essential, in order to, as the findings of Part B in the results section show, obtain a comprehensive overview of a country's SSH output.

Our study had two main limitations. First, our study uses data from national databases which are based on different classification systems (cognitive versus organizational). This may have biased the results on the discipline level and for the comparison between the national databases and the WoS. Currently, however, analysing the total SSH volume in non-English speaking countries is possible only in this way, i.e. on the basis of national databases. Guns et al. (2017) have analysed the discrepancy between these two ways of classifying publications in the social sciences and humanities. They show that, in the VABB-SHW, $70 \%$ of publications from the humanities are published in humanities journals, while only $53 \%$ of publications from the social sciences are published in social sciences journals. Additionally, the types of institutions and personnel reporting to those 
national databases are different across countries. For example, for Flanders data are collected only from universities, whereas in Slovakia only full-time academics report their publications.

Second, we analyse statistics of the peer-reviewed SSH publications regardless of the quality of those publications. In terms of peer review processes, we have taken the collection of those publications that have been marked as peer reviewed at face value for each of the eight countries. We know, however, that peer review comes in many different forms (Lee et al. 2013) and is not determined uniformly across each of the eight databases (e.g. for NSI, authors themselves first indicate whether a publication is peer reviewed or not, whereas in Flanders a central panel decides on the peer review status of publication channels). Even for the same publications channels, these different approaches may lead to differences in terms of peer review status across countries (Pölönen et al. 2017b). Moreover, in terms of quality of publications we measure neither the impact nor the citations of the publications, and we do not analyse whether the growth in terms of number of articles is related to the growth of articles published in top-tier journals or societal impact. Our primary aim is to provide a broader picture of SSH productivity in European countries. Nonetheless, we believe that the quality and impact of the SSH publications used for this analysis is a topic that requires further investigation.

Publication patterns are rooted in scholarly traditions, as the relatively stable cases of Denmark, Finland, Flanders, and Norway show. However, our analysis reveals that discipline-level publication patterns differ more across countries than Sivertsen (2016a) and van Leeuwen (2006) initially suggested. It appears that similarities between disciplines depend not only on the analogies within disciplines but also on the similarities between countries. In comparing the publication patterns from eight European countries, we observed few similarities for comparison at either the country level or the discipline level.

In general, our findings revealed two publication pattern characteristics that should be interpreted in a broader context. The first publication pattern characteristic relates to the proportions of publication types, which appear relatively stable in Denmark, Finland, Flanders, Norway, and Slovenia but were subject to significant change in the Czech Republic and Poland, especially in terms of the share of monographs. Since 2011, in Poland, the proportion of articles has increased, whereas the proportion of chapters has decreased. The number of monographs has decreased significantly as well. An interpretation of these changes is possible when we identify the main underlying mechanisms. In Poland, the regulations for both the performance-based research funding system and for academic promotions changed considerably from 2009 to 2014 (Kulczycki 2017). Furthermore, science policy in Poland has increasingly provided incentives for publishing articles and for publishing in English (Kulczycki et al. 2017b). As for the Czech Republic, the decrease of monographs in 2012 can be interpreted by the change of the evaluation regulations (i.e. Evaluation Methodology) in 2013. In each evaluation year, outputs from the previous year are assessed. Based on these regulations, books and chapters became the subject of panel review. Consequently, many publications were excluded from the database, as they were recognized by panels as inappropriate or even fraudulent according to the definition of the publication type. In the next few years, researchers adopted new conditions and the number of books rose again. The overall ratio of number of books and articles in journals can be interpreted in the context of strategic balancing between the expected number of points in the national evaluation and the effort put in publishing in certain publication channels. Our findings point to the possibility that these policies have achieved some of their intended effects. However, we have not analysed the quality of the articles, for example, in terms of publication channel (e.g. top-tier journals indexed in 
Scopus or the WoS). In other words, what unintended and constitutive effects have occurred remains to be studied.

Another publication pattern and characteristic that requires further attention is related to the publication languages, and in particular, publications that are written in English. Both on the aggregate level and on the discipline level, we found patterns that similarly divided the analysed countries into three groups. In Denmark, Finland, Flanders, and Norway, the majority of the peer-reviewed publications appear in English. In the Czech Republic and Slovenia, publications in English constitute a lower share of the total volume. In Poland, publications written in English constitute the smallest share of all SSH publications from all the analysed countries. However, in all countries at the aggregate level, the growth of English language publications is observed.

The share of publications in English can be interpreted, among other perspectives, in the light of the size of the scientific community in the given countries. In our study, we have analysed eight countries, which were chosen on the basis of data availability. Our initial goal was to analyse all European countries which collect the bibliographic records for all SSH peer-reviewed publications at the national level. In the final dataset, there are six countries whose populations do not exceed 7 million citizens (i.e. Denmark, Finland, Flanders, Norway, Slovakia, and Slovenia). The Czech Republic has 10.5 million citizens, and Poland has 38 million citizens. The size of the population and the size of scholarly community may be important explanatory factors of publication patterns. The 'local' market of academic output may be very different depending on the number of people speaking the local language and the number of small local publishers. However, some local languages are also the local language in other countries (e.g. Dutch in the Netherlands), and in some contexts, it is common for researchers to be able to read each other's publications in the local language because the languages are similar (e.g. Danish and Norwegian).

Poland is one of the biggest European countries (and the largest among the countries analysed in this study). Our findings show that Polish SSH scholars are comparatively less internationally oriented in their publication patterns in terms of writing in English. However, prior to 1989 Polish SSH scholars used to be international. Following a massive expansion of the higher education sector after 1989, Polish SSH scholars lost much of their international research visibility (Kwiek 2014). Smaller countries such as Denmark, Finland, Norway, and Slovenia, with local languages which are not commonly used in other countries, have only small local audiences for scholarly publications in the local language. Thus, scholars from these countries need to be more international in their publication practices from the onset. For instance, Denmark, Finland, Flanders, and Norway have a long tradition of being international in their scholarly publication patterns. They also have a strong tradition of being nationally relevant in research and using the national language, particularly in the SSH. In contrast, however, the Czech Republic, Slovakia, and Slovenia are also small countries, but their internationalization patterns are not similar to those in Denmark, Norway, Finland, or Flanders. Thus, (1) the size of a country and the size of its scientific community may contribute to differences in publication patterns only to some extent, and (2) differences in publication patterns within disciplines in various countries are determined not only by, among other factors, disciplines themselves and the size of countries and scientific communities, but also by the cultural and historical heritage of those countries. Hence, by analysing publications that are written in English, we seek further explanatory factors beyond the disciplines.

An even more important explanatory factor, however, may be the respective $20^{\text {th }}$ century histories of the analysed countries. In the Czech Republic, Poland, and Slovakia, 
Russian was a compulsory language at school prior to 1989, and, from a researcher's point of view, publishing in English was not the best way to communicate research results. Before the achievement of Slovenian independence in 1991, in former Yugoslavia, the Slovene language was one of the official languages. The share of publications in other official languages (Serbian and Croatian) was significant. Since then, in those countries other languages became more prevalent (mostly English and German).

However, SSH scholars from the majority of the Central and Eastern European countries still traditionally investigate only local topics and read and use publications mostly from national or regional journals and publishers. Before 1989, science in former communist countries was strongly politicized. Under communist regimes, all public accountability systems were subordinated to party accountability (Balázs et al. 1995). Therefore, party loyalty was necessary for academic promotions and professional successes. Also, some specificities of the structure of the R\&D system stem from the communist period. The research and higher education systems are still characterised by a split between the Academies of Sciences (e.g. the Academy of Sciences of the Czech Republic and the Polish Academy of Sciences) and university systems, though the two entities increasingly collaborate (Heinecke 2017). The situation in Central and Eastern European countries before and after 1989 may still contribute to the current publication practices in economics and business, which as an academic discipline is substantially less internationally oriented in those countries than in the other countries that were examined in this study. In the Czech Republic, Poland, and Slovakia, economics and business served as one of the main tools of the central planning economy for domestic purposes. After 1989, economics and business had to face other domestic challenges of the transformation from central planning to (turbo) capitalism (Papava 2005).

The transformations of publication patterns are also shaped by science policy and the incentives created by research evaluation systems. As mentioned earlier, large-scale reforms in science and higher education systems in Poland created incentives for publishing in English and choosing articles as a publication type. Some incentives can also be observed in other countries. In the Czech Republic, publication patterns and publication languages may be in general (not only in SSH) directly influenced by the national evaluation system, which influences $100 \%$ of the core funding of research from the state budget. The Czech evaluation system encourages Scopus and WoS journals and proceedings. An article published in a top international journal obtains several times more points than an article published in a journal that concerns "national" fields (e.g. law), focuses on local topics, and is written in Czech (Good et al. 2015). An analogous situation may be observed in Slovakia. In Denmark, the Danish Bibliometric Research Indicator has not been implemented in order to incentivize the Danish authors to publish in English, and while only $9 \%$ of the Danish publication channels on the BFI list of series are on the higher level 2, there is no Danish publisher listed at this level. This results in only $11 \%$ of the publications in SSH written in Danish being on level 2 in 2014. These levels are chosen by the researchers themselves through the Academic Committee and expert panels, which indicates that the Danish authors in SSH are either already focusing on publishing in English or have an external incentive to publish in English.

In Finland, in 2010-2012, 1\% of the annual block grant for universities was allocated on the basis of "international refereed publications", and $0.7 \%$ of the grant was allocated on basis of other publications. In 2013-2014 the share of international refereed publications increased to $9 \%$, and that of other publications increased to $4 \%$. This model promoted international publishing, as refereed journal and book publications published in Finland were counted among other publications together with non-refereed output in international 
outlets. Since 2015, Finland adopted the Norwegian model, in which the weight of publications depends on the publication channel rating (Giménez-Toledo et al. 2016). This model provides incentives for publishing in the national languages, as the majority of peerreviewed publications in Finnish and English language channels are given equal weight at level 1 of the three-tier rating system. In Finland, 22 SSH publication series and three book publishers publishing in national language are also rated as level 2 (Pölönen 2015). Universities are also required under the Universities Act to evaluate their research activities and report the results publicly. Each university decides how it conducts the evaluation and if publication indicators are used. Although some universities use citation analysis or local publication data to inform expert panels, it is unlikely that research evaluation exercises in Finland would affect publication type and/or language selection on the national level (Wang et al. 2014). The Academy of Finland, the main research funding organization in Finland, traditionally uses panels of foreign experts to evaluate applications. In the long term, this practice may have put pressure on SSH researchers to produce more international output profiles (Väyrynen 2006).

In Flanders, the performance-based funding system started out (in 2003) with publications indexed in the WoS only. This may have driven researchers towards the WoS (Ossenblok et al. 2012). In the Norwegian model, the state allocates less than $2 \%$ of the total expenses in the higher education sector (Sivertsen 2016b). Thus, the Norwegian publication indicator attracts attention from researchers because it links directly to their publication practices. In Slovakia, regulations for assessing publications are directly connected to the funds allocation (Ministry of Education, Science, Research and Sport of the Slovak Republic 2017). Therefore, there are direct incentives for researchers to shift their publication outputs towards those types of publications that are within their capacity and allow them to earn more money. In Slovenia, the research evaluation system considers publications indexed in Scopus or the WoS (Science Citation Index Expanded). The small size of the research sector in Slovenia results in a low number of publications indexed in these two international databases. However, the social sciences and humanities exhibited the largest growth in international publications from 1998 to 2005 (Sorčan et al. 2008).

\section{Conclusion}

The findings presented in this study have practical and policy implications. The internationalization policies in non-English speaking countries should be designed with consideration of current publication patterns. Western and Northern European countries have different starting points than Central and Eastern European countries. Scholars in the former group of countries are more rooted in their disciplines internationally and belong more often to a world-wide scholarly community than scholars from the latter group of countries. The Czech and Polish cases illustrate that it may be easy to change publication practices by providing incentives for scholars to publish in more locally oriented scholarly channels. This means that science policy could have strong-both positive and negativeconsequences for the researchers' behaviour. Our results show that in the majority of countries, less than $50 \%$ of SSH publications is visible in WoS. Hence, science policies oriented to university rankings may be interested in developing incentives which will push scholars to publish in journals indexed in Scopus and/or the WoS. However, providing such incentives, though desirable from some science policy points of view, could have negative consequences for SSH publication patterns. As we show, SSH scholars published 
many monographs and chapters which are not included (with some exceptions in the Book Citation Index) in Scopus or the WoS. Our findings follow results presented by Sivertsen and Larsen (2012), who provided empirical evidence that a robust bibliometric database for assessing the impact of all types of research output in SSH is needed. Thus, we suggest that the role of national databases, which cover all publication channels important for the SSH, should be increased in research evaluation systems, funding-schemes, and university rankings.

Acknowledgements The present study is an extended version of an article presented at the 16th International Conference on Scientometrics and Informetrics, Wuhan (China), 16-20 October 2017). The authors are indebted to COST Action CA1537 "European Network for Research Evaluation in the Social Sciences and the Humanities" for supporting this work. Kasper Bruun is employed in the Danish Ministry of Higher Education and Science: positions and views expressed in the paper are solely on the account of the author.

Open Access This article is distributed under the terms of the Creative Commons Attribution 4.0 International License (http://creativecommons.org/licenses/by/4.0/), which permits unrestricted use, distribution, and reproduction in any medium, provided you give appropriate credit to the original author(s) and the source, provide a link to the Creative Commons license, and indicate if changes were made.

Funding The work of Emanuel Kulczycki was supported by the National Programme for the Development of Humanities in Poland [Grant Number 0057/NPHR3/H11/82/2014]. Tim Engels and Raf Guns thank the Flemish Government for its funding of the VABB through the Centre for R\&D Monitoring (ECOOM).

\section{References}

Arnold, E. (2011). International audit of research, development \& innovation in the Czech Republic: Final report: Synthesis report. https://rio.jrc.ec.europa.eu/en/file/8082/download?token=15tMSCU7. Accessed 13 January 2018.

Balázs, K., Faulkner, W., \& Schimank, U. (1995). Transformation of the research systems of post-communist Central and Eastern Europe: An introduction. Social Studies of Science, 25(4), 613-632. https:// doi.org/10.1177/030631295025004002.

COBISS Platform. (2016). Co-operative online bibliographic system and services. https://www.cobiss.net/ cobiss-platform.htm\%0D. Accessed 22 September 2017.

Daraio, C., \& Glänzel, W. (2016). Grand challenges in data integration-State of the art and future perspectives: An introduction. Scientometrics, 108(1), 391-400. https://doi.org/10.1007/s11192-0161914-5.

Engels, T. C. E., Ossenblok, T. L. B., \& Spruyt, E. H. J. (2012). Changing publication patterns in the social sciences and humanities, 2000-2009. Scientometrics, 93(2), 373-390. https://doi.org/10.1007/s11192012-0680-2.

Giménez-Toledo, E., Mañana-Rodríguez, J., Engels, T. C. E., Ingwersen, P., Pölönen, J., Sivertsen, G., et al. (2016). Taking scholarly books into account: Current developments in five European countries. Scientometrics, 107(2), 685-699. https://doi.org/10.1007/s11192-016-1886-5.

Good, B., Vermeulen, N., Tiefenthaler, B., \& Arnold, E. (2015). Counting quality? The Czech performancebased research funding system. Research Evaluation, 24(2), 91-105. https://doi.org/10.1093/reseval/ rvu035.

Guns, R., Engels, T. C. E., \& Verleysen, F. T. (2017). Cognitive and organizational classification of publications in the social sciences and humanities. In 16th international conference on scientometrics and informetrics, ISSI 2017 (pp. 112-117). Wuhan University, China.

Heinecke, S. (2017). On the route towards renewal? The Polish Academy of Sciences in post-socialist context. Science and Public Policy. https://doi.org/10.1093/scipol/scx063.

Hrčková, L., \& Dušková, M. (2011). CREPČ a CREUČ ako unikátny zdroj informácií o publikačnej a umeleckej činnosti vysokých škôl SR. In Informum 2011: sborník ze 17. ročníka konference o profesionálních informačních zdrojich. Praha, 24.-26. května 2011. https://www.inforum.cz/sbornik/2011/ $40 /$. 
Kozak, M., Bornmann, L., \& Leydesdorff, L. (2014). How have the Eastern European countries of the former Warsaw Pact developed since 1990? A bibliometric study. Scientometrics, 102(2), 1101-1117. https://doi.org/10.1007/s11192-014-1439-8.

Kulczycki, E. (2017). Assessing publications through a bibliometric indicator: The case of comprehensive evaluation of scientific units in Poland. Research Evaluation, 26(1), 41-52. https://doi.org/10.1093/ reseval/rvw023.

Kulczycki, E., Engels, T. C. E., \& Nowotniak, R. (2017a), Publication patterns in the social sciences and humanities in Flanders and Poland. In 16th international conference on scientometrics and informetrics, ISSI 2017 (pp. 95-104). Wuhan University, China.

Kulczycki, E., Korzeń, M., \& Korytkowski, P. (2017b). Toward an excellence-based research funding system: Evidence from Poland. Journal of Informetrics, 11(1), 282-298. https://doi.org/10.1016/j.joi. 2017.01.001.

Kwiek, M. (2014). Structural changes in the Polish higher education system (1990-2010): A synthetic view. European Journal of Higher Education, 4(3), 266-280. https://doi.org/10.1080/21568235.2014. 905965.

Lee, C. J., Sugimoto, C. R., Zhang, G., \& Cronin, B. (2013). Bias in peer review. Journal of the American Society for Information Science and Technology, 64(1), 2-17. https://doi.org/10.1002/asi.22784.

Ministry of Education and Culture. (2015). Publication data collection instructions for researchers. https:// confluence.csc.fi/display/suorat/Julkaisutiedonkeruun+tutkijaohjeistukset?preview=/62049905/ 62049919/Publicationdatacollectioninstructionsforresearchers_23-4-2015_en.pdf. Accessed 13 January 2018.

Ministry of Education, Science, Research and Sport of the Slovak Republic. (2012). Vyhláška MŠ SR $\check{c}$. 456/2012 o CREPČ a CREUČ. https://www.minedu.sk/data/att/10876.pdf. Accessed 13 January 2018.

Ministry of Education, Science, Research and Sport of the Slovak Republic. (2017). Metodika rozpisu dotácie zo štátneho rozpočtu verejným vysokým školám 2017. https://www.minedu.sk/data/att/10876. pdf. Accessed 13 January 2018.

Ministry of Higher Education and Science, \& Danish Agency for Science and Higher Education. (2017). Guidelines for registering research for the Danish Bibliometric Research Indicator (Ver. 1.3). https:// ufm.dk/forskning-og-innovation/statistik-og-analyser/den-bibliometriske-forskningsindikator/BFIsregler/guidelines_for_registering_research_for_the_danish_bibliometric_research_indicator.pdf. Accessed 13 January 2018.

Nordforsk. (2018). Comparing research in social sciences and the humanities in the Nordic countries-An explorative study. https://www.nordforsk.org/en/publications/publications_container/comparingresearch-in-social-sciences-and-the-humanities-in-the-nordic-countries-an-explorative-study/ download. Accessed 13 January 2018.

Ossenblok, T. L. B., Engels, T. C. E., \& Sivertsen, G. (2012). The representation of the social sciences and humanities in the Web of Science: A comparison of publication patterns and incentive structures in Flanders and Norway (2005-9). Research Evaluation, 21(4), 280-290. https://doi.org/10.1093/reseval/ rvs019.

PAP Nauka w Polsce. (2017). Prawie 700 uczonych rozpoczęło pracę w Polsce dzięki programowi Marie Skłodowska-Curie Actions. Nauka $w$ Polsce. http://naukawpolsce.pap.pl/aktualnosci/news\% 2C414316\%2Cprawie-700-uczonych-rozpoczelo-prace-w-polsce-dzieki-programowi-mariesklodowska-curie-actions.html. Accessed 13 January 2018.

Papava, V. (2005). On the theory of post-Communist economic transition to market. International Journal of Social Economics, 32(1/2), 77-97. https://doi.org/10.1108/03068290510575658.

Pölönen, J. (2015). Suomenkieliset kanavat ja julkaisut Julkaisufoorumissa. Media \& Viestintä, 38(4), 237-252.

Pölönen, J., Engels, T., Guns, R., Sivertsen, G., \& Verleysen, F. (2017a). SSH journal publishing in Flanders and Finland. In 2nd international conference on research evaluation in the social sciences and humanities, RESSH 2017 (pp. 44-48). https://www.uantwerpen.be/images/uantwerpen/ container41447/files/A5-BOOK_RESSH2017_170717-interactive.pdf. Accessed 13 January 2018.

Pölönen, J., Engels, T. C. E., Guns, R., \& Verleysen, F. T. (2017b). Is my publication peer reviewed? A comparison of top-down and bottom-up identification of peer review in the framework of the Finnish and Flemish performance-based research funding systems. In Science, technology and innovation indicators, STI 2017. Paris, France.

Puuska, H.-M. (2014). Scholarly publishing patterns in Finland: A comparison of disciplinary groups. University of Tampere, Tampere. https://tampub.uta.fi/bitstream/handle/10024/95381/978-951-449480-2.pdf?sequence=1. Accessed 13 January 2018.

SICRIS. (2009). Slovenian current research information system. http://sicris.izum.si/about/cris.aspx?lang= eng\%0D. Accessed 22 September 2017. 
Sīle, L., Guns, R., Sivertsen, G., \& Engels, T. (2017). European databases and repositories for Social Sciences and Humanities research output: Report (July). https://doi.org/10.6084/m9.figshare.5172322.

Sīle, L., Pölönen, J., Sivertsen, G., Guns, R., Engels, T. C. E., Arefiev, P., et al. (n.d.). Comprehensiveness of national bibliographic databases for social sciences and humanities: findings from a European survey. (submitted).

Sivertsen, G. (2014). Scholarly publication patterns in the social sciences and humanities and their coverage in Scopus and Web of Science. In E. Noyons (Ed.), Proceedings of the science and technology indicators conference 2014 Leiden (pp. 598-604). Leiden: Centre for Science and Technology Studies.

Sivertsen, G. (2016a). Patterns of internationalization and criteria for research assessment in the social sciences and humanities. Scientometrics, 107(2), 357-368. https://doi.org/10.1007/s11192-016-1845-1.

Sivertsen, G. (2016b). Publication-based funding: The Norwegian model. In M. Ochsner, S. E. Hug, \& H.-D. Daniel (Eds.), Research assessment in the humanities: Towards criteria and procedures (pp. 79-90). Cham: Springer. https://doi.org/10.1007/978-3-319-29016-4_7.

Sivertsen, G., \& Larsen, B. (2012). Comprehensive bibliographic coverage of the social sciences and humanities in a citation index: An empirical analysis of the potential. Scientometrics, 91(2), 567-575. https://doi.org/10.1007/s11192-011-0615-3.

Sorčan, S., Demšar, F., \& Valenci, T. (2008). Znanstveno raziskovanje v Sloveniji. Ljubljana: Javna agencija za raziskovalno dejavnost Republike Slovenije.

van Leeuwen, T. (2006). The application of bibliometric analyses in the evaluation of social science research. Who benefits from it, and why it is still feasible. Scientometrics, 66(1), 133-154. https://doi. org/10.1007/s11192-006-0010-7.

Väyrynen, R. (2006). Suomenkielinen tiede. Tieteessä Tapahtuu, 24(3), 31-34. https://journal.fi/tt/article/ view/56596. Accessed 13 January 2018.

Verleysen, F. T., Ghesquière, P., \& Engels, T. C. E. (2014). The objectives, design and selection process of the Flemish Academic Bibliographic Database for the Social Sciences and Humanities (VABB-SHW). In W. Blockmans, L. Engwall, \& D. Weaire (Eds.), Bibliometrics Use and Abuse in the Review of Research Performance (pp. 117-127). London: Portland Press. http://www.portlandpress.com/pp/ books/online/wg87/087/0117/0870117.pdf. Accessed 13 January 2018.

Vipunen. (2017). Vipunen-Education statistics Finland. https://vipunen.fi/en-gb/. Accessed 13 January 2018.

Wang, L., Vuolanto, P., \& Muhonen, R. (2014). Bibliometrics in the research assessment exercise reports of Finnish universities and the relevant international perspectives. Working Papers, 10. Tampere. https:// uta32-kk.lib.helsinki.fi/bitstream/handle/10024/96266/bibliometrics_in_the_research_2014. pdf?sequence $=1$. Accessed 13 January 2018. 